\title{
POŠTA
}

TELEKOMUNIKACIE A

ELEKTRONICKY OBCHOD

\section{IMPLEMENTACE SYSTÉMU MANAGEMENTU KVALITY DLE ISO 9001 NA DFJP UNIVERZITY PARDUBICE JAKO MOŽNOST ŘEŠENÍ ŘÍDÍCÍCH PROBLÉMŮ}

\author{
Libor Švadlenka*
}

\section{Úvod}

Stávající způsoby řízení veřejných vysokých škol bývají postaveny na principech „zvykového práva“, které již nekorelují s aktuálními požadavky dynamicky se vyvíjející společnosti. Mnoho problémů a často i téměř standardních situací se řeší ad hoc způsobem. Zejména $\mathrm{v}$ případě rozdělování finančních prostředků a řízení finančních toků se tento ad hoc přístup, který není postaven na jasně měřitelných kritériích, může stát problémem z hlediska dlouhodobého programování chodu univerzity. V řadě př́ípadů jsou nejasně vymezené kompetence, a tím i zodpovědnosti. Celému způsobu řízení chybí požadovaná úroveň transparentnosti a formalizace.[7]

Nutno konstatovat, že tyto problémy trápí i Univerzitu Pardubice, resp. její Dopravní fakultu Jana Pernera (dále jen DFJP). Řešením této situace by mohlo být implementace účinného SMK jako nedílné součásti řízení. Implementace takovéhoto systému by totiž vedla k přesnému vymezení kompetencí a odpovědností, k lepší organizaci uvnitř fakulty, k nutnosti zkoumání a uspokojování reálných potřeb zákazníků, resp. zainteresovaných stran, k úsporám nákladů na provoz pracovišt' a zejména ke zkvalitnění výukového procesu.

Některé vysoké školy (TU Wien, TU Aachen, Ekonomická fakulta UMB v Bánské Bystrici, fakulty VSB-TU Ostrava apod.) se již touto cestou vydaly, tj. mají implementovány účinné SMK (certifikované podle normy ISO 9001), a tak lze v prvních fázích využít jejich zkušeností.

\section{Postup implementace SMK}

SMK lze implementovat:

- $\quad$ využitím poradenské či konzultační firmy,

- $\quad$ vlastními silami.

Společný je pro oba uvedené způsoby první a zdaleka nejdůležitější krok při implementaci účinného SMK, a to kladné rozhodnutí vedení fakulty o její realizaci. Zde je třeba zdůraznit, že pouhé formální kladné rozhodnutí je naprosto nedostačující. Vedení fakulty musí být $\mathrm{v}$ průběhu celého procesu implementace svým přístupem př́kladem celé fakultě, a proto je nezbytná jeho angažovanost, tj. aktivní účast založená na hlubokém přesvědčení o smysluplnosti celého projektu.

\footnotetext{
* Ing. Libor Švadlenka, Ph.D., Univerzita Pardubice, Dopravní fakulta Jana Pernera, Katedra dopravního managementu, marketingu a logistiky, Studentská 95, 53210 Pardubice, Tel.: 466036375, E-mail: Libor.Svadlenka@upce.cz
} 


\section{a. Postup implementace SMK s pomocí poradenské firmy}

V př́padě využití poradenské firmy by postup implementace SMK na DFJP mohl probíhat následovně.

- Úvodní pohovor poradenské firmy s vedením DFJP (určení požadavků, způsoby zavádění SMK, stanovení cílů, postup prací). Cílem by mělo být podepsání smlouvy o spolupráci.

- Úvodní seminář pro vedení DFJP (struktura norem řady ČSN EN ISO 9000, stav a trendy, požadavky na SMK). Výstupem mohou být učební texty pro účastníky, osvědčení o absolvování atd.

- Analýza stávajícího stavu formou přímého šetření na místě (srovnání stavu ve firmě s požadavky normy ČSN EN ISO 9001). Výstupem může být zpráva o stavu, výběr priorit činností, definování silných a slabých stránek, upřesnění doby zavádění SMK atd.

- Vytvoření rady resp. týmu kvality (jmenováním představitele vedení pro kvalitu, popř. ustavení pracovních týmů). Cílem by mělo být vytvoření personálních předpokladů pro úspěšné budování, udržování a zlepšování SMK.

- Definování hlavních procesů formou konzultací (stanovení priorit postupu v závislosti na určených procesech, stanovení měřitelných cílů). Výstupem etapy je harmonogram systémových opatření, vzniku dokumentace, kontrol, odpovědnosti za jednotlivé činnosti.

- Dokumentování SMK (směrnice, postupy, záznamy, základy př́ručky kvality), tj. výstupem je návrh, tvorba, schválení a vydání dokumentů k SMK.

- Zavádění systému do praxe formou konzultací (pravidelná práce rady resp. týmu kvality, zavedení systémových změn). SMK se v této etapě stává součástí managementu DFJP .

- Průběžné vzdělávání formou krátkodobých seminářů pro všechny zaměstnance, znalost dokumentů, pochopení systémových změn. Cílem by měla být znalost všech zaměstnanců o SMK, motivace pro tento systém a zlepšování práce.

- Interní audity formou šetření na místě, tzn. průběžné kontroly úplnosti SMK, splnění požadavků normy ČSN EN ISO 9001, prověření funkčnosti, účinnosti a dodržování.

- Přezkoumání SMK vedením DFJP (posouzení auditů, hodnocení účinnosti a funkčnosti systému, jeho silné a slabé stránky, plnění cílů, hodnocení spokojenosti zákazníků). Výstupem je zpráva o kvalitě včetně stanovení nových cílů a posouzení připravenosti k certifikaci.

- Podání žádosti k certifikaci, tj. hodnocení a výběr certifikační společnosti, podání žádosti. To směřuje ke smlouvě s certifikační společností.

- $\quad$ Certifikace formou certifikačního auditu, kdy výstupem je certifikát.

- $\quad$ Poradenská firma by tedy měla dovést DFJP přes úskalí výše uvedených etap až k samotné certifikaci SMK dle požadavků ČSN EN ISO 9001. Pokud jde o časové hledisko, poradenské firmy většinou udávají dobu potřebnou pro implementaci SMK řádově v měsících v závislosti na současném stavu SMK a počtu zaměstnancủ.

\section{b. Postup implementace SMK dle ISO 9001 vlastními silami}

Celý implementační proces končící obdržením certifikátu kvality lze přehledně znázornit postupovým diagramem uvedeném na Obr. 1 (aby mohl být postupový diagram celý zobrazen na jedné stránce, je pro zjednodušení na výstupu každé etapy znázorněna značka pouze jednoho dokumentu, přestože jich je více ). 


\section{Iniciační etapa}

V rámci této počáteční etapy se předpokládají následující činnosti:

- Příprava a školení vedení DFJP zahrnující strukturu norem ISO řady 9000, požadavky na SMK, analýzu stávajícího stavu, budoucí trendy apod.

- Jmenování představitele vedení DFJP pro kvalitu, případně manažera kvality

- Ustanovení řešitelského týmu

- Jmenování interních auditorů

- Stanovení úkolů a přiřazení kompetencí zapojeným osobám

Detailní rozpracování této etapy $\mathrm{v}$ podobě plánu, včetně přiřazení kompetencí jednotlivým osobám by mělo být realizováno např́iklad formou tabulky, která by mohla být zároveň vzorem pro plánování následných etap.

\section{Př́pravná etapa}

V rámci této etapy by měly být realizovány činnosti:

- $\quad$ Formulace vize a mise fakulty

- $\quad$ Formulace politiky kvality

- $\quad$ Stanovení cílů kvality

- Příprava a školení řešitelského týmu zaměřené na správné posouzení shody požadavků ČSN ISO 9001 se stávajícím stavem SMK.

Při detailním plánování této a následných etap včetně rozdělení kompetencí by se pak opět použila podobná tabulka jako v 2.2.1.V této etapě je rozhodující týmová práce vedení DFJP při sestavování návrhu a následném přezkoumání základních strategických dokumentů DFJP, samozřejmě při průběžné komunikaci se všemi nižšími řídícími úrovněmi fakulty. Odpovědnost za formulaci a stanovení těchto dokumentů by měl mít děkan DFJP. Jejich obsah a forma musí odpovídat požadavkům ČSN EN ISO 9001. 
Obr. 1: Postupový diagram implementace SMK na DF JP

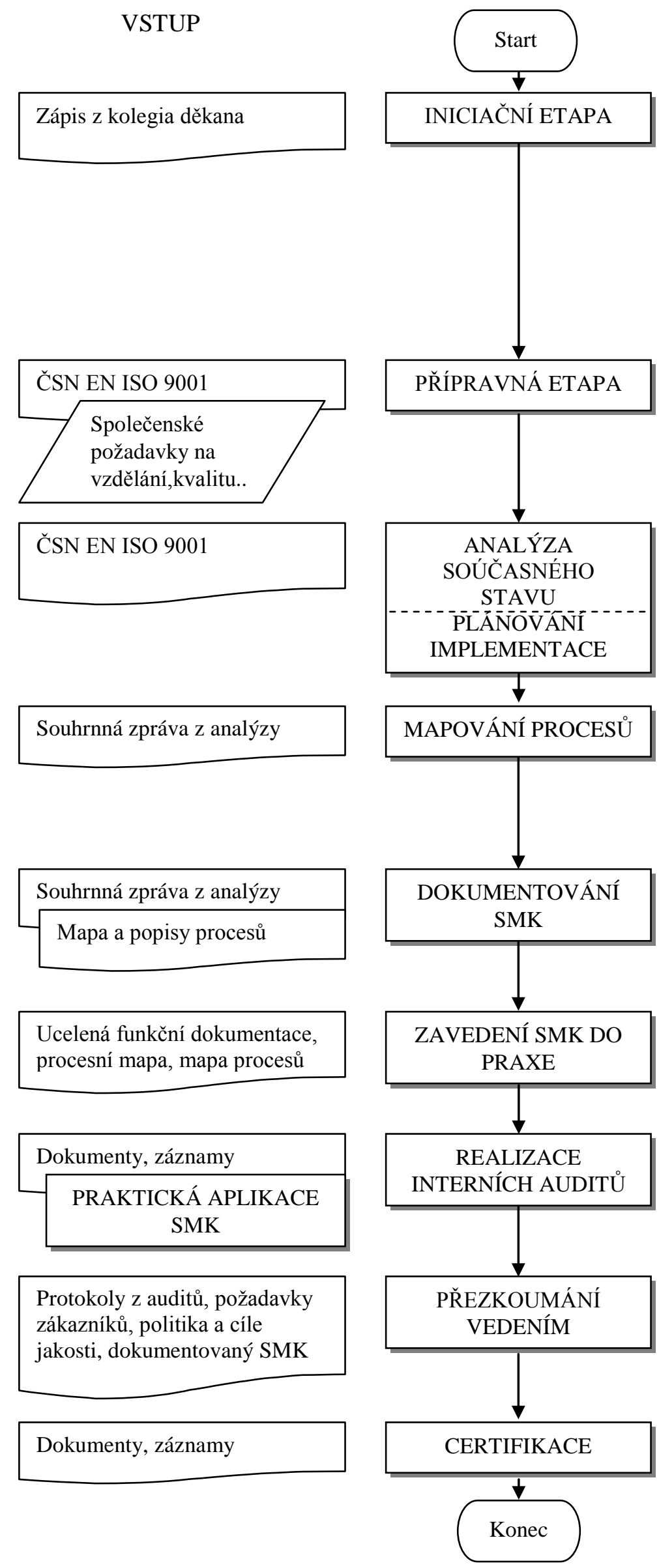

VÝSTUP

Obsahová náplň školení, materiály ze školení, zápis ze školení, jmenovací dekret představitele pro kvalitu př́ip. manažera kvality, zápis ze jmenování řešitelského týmu, interních auditorů, zápis o rozdělení kompetencí

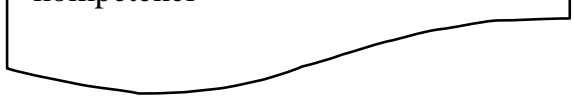

Vize a mise DFJP, politika kvality, obsahová náplň školení, materiály ze školení, zápis ze školení

Souhrnná zpráva o současném stavu SMK

Plán implementace

Obsahová náplň školení, materiály ze školení, zápis ze školení, schémata a popisy procesů, mapa procesů, návaznosti procesů

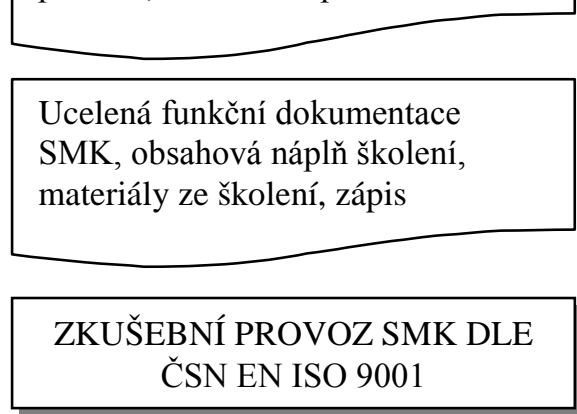

Obsahová náplň školení, materiály ze školení, zápis ze školení, protokoly $\mathrm{z}$ auditu

Zpráva o jakosti, definované nové cíle, identifikované potřebné zdroje, zpráva o připravenosti $\mathrm{k}$ certifikaci

Certifikát jakosti 


\section{Etapa analýzy současného stavu a plánování implementace}

V rámci této etapy by měly být realizovány následující činnosti:

- Vytvoření dotazníku pro hodnocení současného stavu SMK

- Vlastní realizace analýzy - důraz na identifikaci struktury a stavu řízení DFJP, způsob rozdělení pravomocí a odpovědností, identifikaci procesů a jejich návazností, strukturu a rozsah existující dokumentace, identifikaci zákazníka a jeho požadavků, stav ekonomického plánování, péče o zaměstnance, stav evidence dat týkajících se kvality a efektivity práce a jejich využití při řízení a následně zjištění základních odchylek od požadavků normy ČSN EN ISO 9001

- Vyhodnocení současného stavu SMK

- Formulování návrhů na systémové změny v souvislosti se zjištěnými neshodami s normou ČSN EN ISO 9001

- Vypracování harmonogramu zavedení SMK dle ČSN EN ISO 9001

\section{Etapa mapování procesů}

V rámci této etapy by měly být realizovány následující činnosti:

- Příprava a školení všech zaměstnanců zaměřené na pochopení SMK, motivaci pro jeho zlepšování a zejména procesní př́ístup včetně metodiky modelování procesů

- Identifikace hlavních, rrídících a podpůrných procesů potřebných pro SMK

- Určení návazností mezi procesy

- Sestavení mapy procesů

- Určení vlastníků procesů

Definovaní vlastníci procesů, musí následně každý takto definovaný proces detailně popsat obvykle pomocí charakteristik jakými jsou účel a cíl procesu, vlastník procesu, zákazník procesu, vstup a výstup tohoto procesu, potřebné zdroje, regulátory, měřitelná kritéria a cíle a samozřejmě vlastní postup přeměny vstupů na výstupy daného procesu.

\section{Etapa dokumentování SMK}

V rámci této etapy by měly být realizovány následující činnosti:

- $\quad$ Stanovení struktury a jednotlivých úrovní dokumentace

- Definice jednotného názvosloví a formy směrnic, pracovních postupů a záznamů

- Doplnění chybějících dokumentů, tj. návrh, připomínkování a schválení dokumentů, které požaduje norma ČSN EN ISO 9001

- Zpracování př́ručky kvality

- Příprava a školení zaměstnanců týkající se nově vytvořeného SMK respektujícího ČSN EN ISO 9001 včetně řízení dokumentace

- Možná struktura dokumentace SMK na DFJP je zřejmá z Obr. 2.

Obr. 2: Hierarchie dokumentů SMK

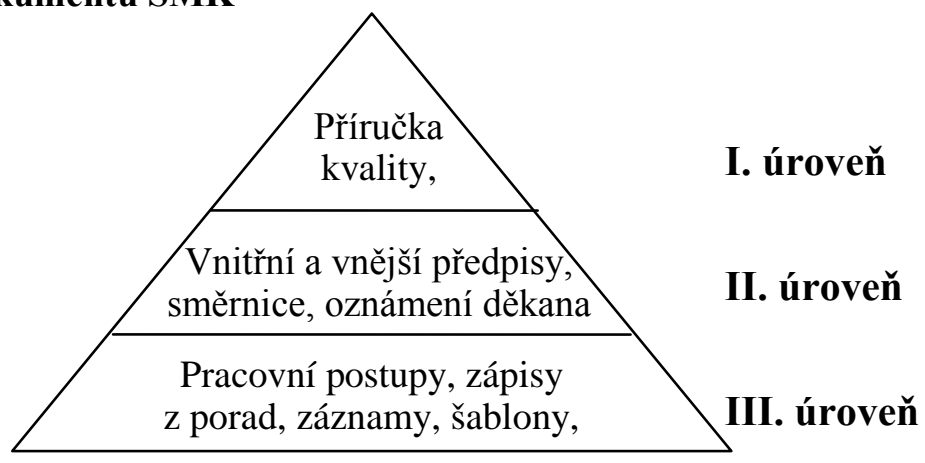


Při tvorbě dokumentace SMK se obvykle začíná směrnicí upravující vznik a řízení dokumentů a záznamů SMK, která zároveň svým formálním uspořádáním a grafickou podobou předepisuje způsob provedení dalších směrnic, které vzniknou v rámci budování a zdokonalování SMK. Tato směrnice také definuje formální vzory (včetně značení) dalších dokumentů v rámci SMK. Je zřejmé, že formální úprava dokumentů SMK DFJP musí zároveň respektovat příslušné pokyny vydané Univerzitou Pardubice týkající se této oblasti.

Příručka kvality je základním dokumentem SMK. Její vytvoření a udržování vyplývá z konkrétního požadavku normy ČSN EN ISO 9001 (článek 4.2.2).

Příručka kvality by měla popisovat SMK budovaný na DFJP v souladu s ČSN EN ISO 9001. Měla by poskytovat základní informace o fakultě, její misi, vizi, politice kvality a cílech kvality, a tím být používána i pro externí účely jako prostředek pro zvýšení důvěry u svých zákazníků a jiných zainteresovaných stran. Měla by být důkazem uplatňování efektivního SMK, a proto by měla přesně, úplně a výstižně vyjadřovat záměry, řídící a realizační postupy fakulty resp. odkazy na tyto postupy v souladu s procesy podle ČSN EN ISO 9001.

Př́ručka kvality by měla být př́stupná pro všechny zaměstnance fakulty, kteří by měli být s obsahem seznámeni a měla by být revidována minimálně jedenkrát ročně

\section{Etapa zavedení SMK do praxe}

$\mathrm{V}$ rámci této etapy by měly být realizovány následující činnosti:

- Zavedení procesního řízení

- $\quad$ Vydání a distribuce dokumentace SMK

- Z Zkušební provoz a v jeho rámci vyhledávání chyb a problematických míst

- „Vylad’ování“ SMK

V rámci této etapy se tedy postupně zavádí jednotlivé hotové procesy a související dokumentace do zkušebního provozu.

\section{Etapa realizace interních auditů}

$\mathrm{V}$ této etapě se předpokládají činnosti:

- Př́prava a školení interních auditorů

- $\quad$ Systematická kontrola budovaného SMK

- $\quad$ Realizace opatření k odstranění rozdílů s požadavky normy ČSN EN ISO 9001

Systematičnost kontroly by měla vycházet především $\mathrm{z}$ jasně definovaného plánu interních auditů. Tento rámcový plán by měl být doplněn sérií detailních plánů jednotlivých, v rámcovém plánu naplánovaných, auditů. Tyto detailní plány by měly zejména obsahovat kdy se bude konkrétní audit realizovat, kým se bude realizovat (ustavení týmu auditorů) a co se bude konkrétně auditovat (např. soulad SMK s články 4.1, 5, 6 a 8 normy ČSN EN ISO 9001). Výsledky těchto jednotlivých auditů by pak měly být zaznamenány do tzv. protokolu z auditu, který by měl také obsahovat zjištěné neshody, př́padně návrhy na jejich odstranění včetně termínů. Samozřejmostí by mělo být důsledné trvání na realizaci nápravných opatření.

\section{Etapa přzkoumání vedením}

V rámci této etapy se předpokládají následující činnosti:

- $\quad$ Posouzení auditů

- Hodnocení účinnosti a funkčnosti SMK

- Posouzení plnění definovaných cílů

- Hodnocení spokojenosti zákazníků

- Vypracování souhrnné zprávy, přijetí a realizace opatření 
Přezkoumání SMK vedením DFJP je pravidelná aktivita striktně vyžadovaná normou ČSN EN ISO 9001 (konkrétně článkem 5.6).

Výstupem této etapy by mělo být vypracování souhrnné zprávy o kvalitě, jejíž součástí by mělo být mimo jiné stanovení nových cílů kvality, včetně potřebných zdrojů a také posouzení prripravenosti SMK k certifikaci.

\section{Etapa certifikace}

Certifikaci lze definovat jako „činnost třetí strany, kterou prokazuje dosažení přiměřené důvěry, že náležitě identifikovatelný výrobek, proces, kvalifikace personálu či systém kvality je ve shodě s předepsanou normou nebo jiným normativním dokumentem"[7]. Výsledkem certifikačního procesu je udělení či neudělení osvědčení o dosažení shody.

Tato závěrečná etapa by měla zahrnovat následující činnosti:

- Hodnocení a výběr certifikační společnosti

- $\quad$ Předaudit

- Certifikační audit - udělení certifikátu

- Kontrolní audity

- Reaudit

Kontrolní audity jsou realizovány namátkově v období mezi certifikačním auditem a reauditem certifikačním orgánem za účelem potvrzení oprávněnosti držení certifikátu.

Po uplynutí platnosti certifikátu musí certifikační orgán provést reaudit v rozsahu certifikačního auditu.

\section{Závěr}

Je zřejmé, že úspěšná implementace SMK dle ISO 9001 na DFJP nebude levná, ani rychlá záležitost. Zejména z dlouhodobého hlediska však př́nosy efektivního, certifikovaného SMK převáží veškerá úskalí spojená s jeho zavedením. Navíc, jak již bylo zmíněno, lze využít zkušeností a know-how organizací, které tento proces již absolvovaly.

Pravděpodobnější variantou prŕípadné implementace SMK dle ISO 9001 na fakultu bude zřejmě varianta využívající vlastní síly než př́ípadná spolupráce poradenské firmy. Celkově by celý proces implementace, jehož výsledkem by byl udělený certifikát kvality, měl trvat přibližně jeden rok.

Nutno však zdůraznit, že úspěšnou certifikací SMK nekončí potřeba o jeho péči, nebot' v souladu se zásadou managementu kvality podle norem řady ISO 9000 by cílem každé organizace mělo být neustálé zlepšování.

\section{Seznam literatury}

[1] ČSN EN ISO 9000:2001 Systémy managementu jakosti - Základy, zásady, slovník.

[2] ČSN EN ISO 9001:2001 Systémy managementu jakosti - Požadavky.

[3] ČSN EN ISO 9004:2001 Systémy managementu jakosti - Směrnice pro zlepšování výkonnosti.

[4] ISO/IWA 2:2003 Systémy managementu kvality - Směrnice pro aplikaci ISO 9001:2000 ve vzdělávání. První vydání. Praha : Národní informační stř̌edisko pro podporu jakosti, 2004. 130 s. ISBN 80-7283-146-1.

[5] HUTYRA, M. Zkušenosti se zaváděním systému managementu jakosti dle ISO 9001:2000 na vysoké škole. In Sborník z konference České společnosti pro jakost, 2004. ISBN 80-0201673-4. 
[6] VONDÁK, I. Proč zavádět systém managementu jakosti na univerzitní pracoviště. AULA, roč. 13, č. 3/2005, str. 26-31, CSVŠ Praha. ISSN 1210-6658.

[7] NENADÁL, J. a kol. Moderní systémy řizení jakosti. Vydání 2. (doplněné;dotisk). Praha: Management Press, 2005. 282 s. ISBN 80-7261-071-6.

[8] Internetové stránky poradenské firmy DERS [online]. [cit. 2006-07-06]. Dostupné z WWW: <http://www.ders.cz>. 